\title{
Monitoring Employees at Workplace from the Perspective of Data Protection
}

\author{
Sena Karaduman İşlek \\ ARI Attorneys at Law, Turkey
}

\begin{abstract}
There always has been a discussion of the privacy in the workplace. Employers can monitor their employees either by placing camera in the workplace, or by accessing the e-mails of employees, or by tracking their vehicles etc. In every sector, employers wish to keep up with the performances of employees or the work at hand. The legitimate expectations of employers to monitor their employees have to be in compliance with the rules of personal data protection law. Especially with the recent situation, the need to protect the privacy of employees must be extended to the remote working. Regulating this area by legislation could be a solution to minimize the risk of privacy of employees. However, employers must act very carefully in this scope and the general principles of personal data protection law and the criteria decided by court decisions must be followed by employers.
\end{abstract}

Keywords: employment; human rights; privacy; remote working; surveillance

\section{Introduction}

According to many source, personal data can be regarded as "any information relating to an identified or identifiable natural person". The right of protection of personal data has always been in the legislation of many countries for many years. However, for the last couple of years, especially when the General Data Protection Regulation (GDPR) came into effect, the concept has become more and more important. One of the examples of the indication of the right of protection of personal data was in the Treaty on Functioning of the European Union and Charter of the Fundamental Rights of the European Union. According to these treaties, "everyone has the right to the protection of personal data concerning them". ${ }^{1}$ On $25^{\text {th }}$ May 2018, the GPDR has come into effect and it has direct applicability on all the members of the European Union. The GDPR has been a milestone in the data protection area and all European Union members are subjected to it.

There always has been a discussion of the privacy in the workplace. Some countries regulate this issue in the national legislation. While monitoring employees in any way, employers must follow the rules of data protection. Especially they must bear the general principles of processing of personal data in mind.

\footnotetext{
1 Treaty on Functioning of the European Union https://eur-lex.europa.eu/legalcontent/EN/TXT/?uri=celex\%3A12012E\%2FTXT and Charter of Fundamental Rights of the European Union https://eur-lex.europa.eu/legal-content/EN/TXT/?uri=CELEX\%3A12012P\%2FTXT
} 


\section{Monitoring Employees at Workplace}

Employers usually would like to keep updated with the work by way of tracking employee or they wish to see the performance of employee. With legitimate means and aims, it could be done but they must draw a line by taking into the rules of data protection account.

\subsection{Ways of Monitoring}

Monitoring or tracking employees may be done in many ways. In this paper, accessing the correspondences of employees, camera surveillances in the workplace and tracking GPS devices of the vehicles of company is given as an example and these ways will be explained in a case-by-case basis.

Employers must act very carefully in this scope and the general principles of personal data protection law and the criteria decided by court decisions must be followed.

\subsubsection{Accessing Correspondences of Employees}

In the decision of Bărbulescu v. Romania of the European Court of Human Rights ${ }^{2}$, employer recorded his employee's Yahoo Messenger communications and applicant was informed that his Yahoo Messenger communications had been monitored because he was aware that the tools cannot be used for personal purposes. Hence, there was evidence that he had used the tools for personal purposes, which was in breach of the internal regulations that he had been informed. However, he was not informed whether the monitoring of his communications had also concerned their content. His employer showed him the forty-five pages of the messages with his brother and his fiancée.

According to the opinion of the Article 29 Working Party, employers should always take fundamental data protection principles into account, which are finality, transparency, legitimacy, proportionality, accuracy, security and staff awareness. ${ }^{3}$ The Court ruled some important criteria for employers as quoted:

(i) whether the employee has been notified of the possibility that the employer might take measures to monitor correspondence and other communications, and of the implementation of such measures. While in practice employees may be notified in various ways depending on the particular factual circumstances of each case, the Court considers that for the measures to be deemed compatible with the requirements of Article 8 of the Convention, the notification should normally be clear about the nature of the monitoring and be given in advance;

(ii) the extent of the monitoring by the employer and the degree of intrusion into the employee's privacy. In this regard, a distinction should be made between monitoring of the flow of communications and of their content. Whether all communications or only part of them have been monitored should also be taken into account, as should the question whether the monitoring was limited in time and the number of people who had access to the results. The same applies to the spatial limits to the monitoring;

\footnotetext{
${ }^{2}$ European Court of Human Rights, Bărbulescu v. Romania, Application No: 61496/08, 5 September 2017 , https://hudoc.echr.coe.int/spa\#\{\%22itemid\%22:[\%22001-177082\%22]\}

3 Article 29 Working Party Opinion 8/2001 on the processing of personal data in the employment context https://ec.europa.eu/justice/article-29/documentation/opinion-recommendation/files/2001/wp48_en.pdf, p.3
} 
(iii) whether the employer has provided legitimate reasons to justify monitoring the communications and accessing their actual content Since monitoring of the content of communications is by nature a distinctly more invasive method, it requires weightier justification;

(iv) whether it would have been possible to establish a monitoring system based on less intrusive methods and measures than directly accessing the content of the employee's communications. In this connection, there should be an assessment in the light of the particular circumstances of each case of whether the aim pursued by the employer could have been achieved without directly accessing the full contents of the employee's communications;

(v) the consequences of the monitoring for the employee subjected to it; and the use made by the employer of the results of the monitoring operation, in particular whether the results were used to achieve the declared aim of the measure;

(vi) whether the employee had been provided with adequate safeguards, especially when the employer's monitoring operations were of an intrusive nature. Such safeguards should in particular ensure that the employer cannot access the actual content of the communications concerned unless the employee has been notified in advance of that eventuality. ${ }^{4}$

As another example, Norway Data Protection Authority issued three fines lately for forwarding e-mails of employees to employers. In one of the cases, employee forwarded emails for sick leave but it has continued for more than a month. The Authority ruled that this must be done by way of informing the employee and it should be subjected to some certain rules. ${ }^{5}$ In the other case, the employee was asked to set up automatic forwarding from their emails to a common e-mail box of the company. This must have been done out of consideration for operations. To sum up, the Authority has fined the company and ordered that the company must improve internal control and its own guidelines for access to employees' e-mail boxes. ${ }^{6}$

Additionally, Turkish Constitutional Court ruled important decisions on monitoring employees. In one of the decisions lately ruled, the applicant was fired after his employer accessed his e-mails and the e-mails were the reasons that he was fired. The Court ruled that accessing e-mails must be done by given a beforehand information and must have certain rules like stated in the Bărbulescu judgment. ${ }^{7}$ In another decision of Turkish Constitutional Court, employer was found right to access e-mails of employee because he was conducting another job via his e-mail and everyone was complaining that he had lowered his performances lately. The Court ruled that employee was informed by way of the contract and there was a legitimate purpose of the employer. ${ }^{8}$ It should also be noted that the applicant didn't contest how the accessing and auditing were made by employer.

\footnotetext{
${ }^{4}$ See supra note 2, para. 121

5 https://www.datatilsynet.no/regelverk-og-verktoy/lover-og-regler/avgjorelser-fra-datatilsynet/2021/far-gebyrfor-videresending-av-e-post/

${ }^{6}$ https://www.datatilsynet.no/aktuelt/aktuelle-nyheter-2021/far-gebyr-for-ulovlig-videresending-av-e-post/ ; For another example, see https://www.datatilsynet.no/regelverk-og-verktoy/lover-og-regler/avgjorelser-fradatatilsynet/2021/cyberbook-as-far-gebyr/

7 Turkish Constitutional Court, Application No: 2016/13010, 17 September 2020, https://kararlarbilgibankasi.anayasa.gov.tr/BB/2016/13010?BasvuruNoYil=2016\&BasvuruNoSayi=13010

8 Turkish Constitutional Court, Application No: 2018/31036, 12 January 2021, https://kararlarbilgibankasi.anayasa.gov.tr/BB/2018/31036
} 
To sum up, it should be underlined that employers can have a control mechanism but it should be done under specific measures.

\subsubsection{Camera Surveillances in the Workplace}

On $8^{\text {th }}$ January 2021, Germany's State Commissioner for Data Protection in Lower Saxony issued a 10.4 million euro fine to retailer "notebooksbilliger.de" for monitoring its employees for two year without a legal basis. ${ }^{9}$ The cameras recorded workplaces, sales rooms, warehouses and common areas. Employer claimed that the aim of putting video cameras in the workplace was to prevent and investigate criminal offenses and to track the flow of goods in the warehouses. ${ }^{10}$ With legitimate purposes, employer can track employees but there are some certain rules. For instance, in this case, the employers could have monitored employees for a limited period of time and by informing employees beforehand about the scope of the surveillance. This fine is regarded as the highest fine that the afore-mentioned Authority issued due to General Data Protection Regulation.

\subsubsection{Tracking GPS Devices of the Vehicles of Company}

On $25^{\text {th }}$ February 2021, it is announced that Spain's Social Chamber of the Supreme Court ruled that a practice done by Telepizza was not compatible with the rules of privacy. ${ }^{11}$ Telepizza launched a project named Tracker Project, which is a system that the employer track location of delivery men on deliveries. The Court ruled that the employer was not transparent about the tracking practices of the project. Even if the ways of tracking are changed, there is one strict rule: employers must be transparent on the scope of tracking.

\subsubsection{Other Means}

On $1^{\text {st }}$ October 2020, the Hamburg Commissioner for Data Protection and Freedom of Information fined H\&M with 35 million euro fine due to the fact that the auditors of the company had a practice of "Welcome Back Talks" in which they asked employees how their leaves were and record what they have done in this period.12 For sick leaves, the information on sickness which is regarded as health data was being recorded. Health data is counted as sensitive personal data and it should be processed under certain circumstances. Additionally, for other leaves for example their family status or information on their personal lives, maybe religious believes could have been recorded. Furthermore, these records could be seen by 50 managers and stored in permanent data stores.

\section{Conclusion}

As it is underlined above, monitoring employees can only be done by following some certain rules. Firstly, employers should have a legitimate business purpose to monitor their

\footnotetext{
9 https://lfd.niedersachsen.de/startseite/infothek/presseinformationen/lfd-niedersachsen-verhangt-bussgeld-uber10-4-millionen-euro-gegen-notebooksbilliger-de-196019.html

${ }^{10}$ European Data Protection Board, State Commissioner For Data Protection in Lower Saxony Imposes $€ 10.4$ Million Fine Against Notebooksbilliger.De, https://edpb.europa.eu/news/national-news/2021/statecommissioner-data-protection-lower-saxony-imposes-eu-104-million-fine en

11 https://www.poderjudicial.es/cgpj/es/Poder-Judicial/Noticias-Judiciales/El-Tribunal-Supremo-confirma-lanulidad-del-proyecto-de-Telepizza-que-obliga-a-los-repartidores-a-aportar-su-movil-personal-para-sugeolocalizacion

12 The Hamburg Commissioner for Data Protection and Freedom of Information, $1^{\text {st }}$ October 2020, https://datenschutz-hamburg.de/assets/pdf/2020-10-01-press-release-h+m-fine.pdf
} 
employees. ${ }^{13}$ Secondly, employers must be transparent and as a data controller, they must inform their employees about the context of monitoring. Employers must also place cameras in places where the cameras would not record their private life. For instance, the cameras could not monitor the whole screen of the computers of employees. Fourthly, employers should set a limit on the storage of the records. For example, as mentioned above, employers could not record employees for two-year span without any legal basis. Another issue to be discussed is that the accessing to these records. Employers must limit the access of the processed data. Last but not least, as a general principle of processing of personal data, when employers monitor employees, they must follow the principle of proportionality and monitoring should not interfere with the privacy of employees.

\section{References}

Article 29 Working Party Opinion 8/2001 on the processing of personal data in the employment context https://ec.europa.eu/justice/article-29/documentation/opinionrecommendation/files/2001/wp48_en.pdf

Charter of Fundamental Rights of the European Union https://eur-lex.europa.eu/legalcontent/EN/TXT/?uri=CELEX\%3A12012P\%2FTXT

European Court of Human Rights, Bărbulescu v. Romania, Application No: 61496/08, 5 September 2017, $\quad$ https://hudoc.echr.coe.int/spa\#\{\%22itemid\%22:[\%22001$177082 \% 221\}$

European Data Protection Board, State Commissioner For Data Protection in Lower Saxony Imposes $€ \quad 10.4$ Million Fine Against Notebooksbilliger.De, https://edpb.europa.eu/news/national-news/2021/state-commissioner-data-protectionlower-saxony-imposes-eu-104-million-fine en

Friedman, B. A., Reed, L. J., Workplace Privacy: Legal and Employee Relations Implications of Monitoring Employee E-Mail Use, Proceedings of the $13^{\text {th }}$ Annual International Conference 2005, Association on Employment Practices and Principles, September 2005 , https://www.researchgate.net/publication/225577056_Workplace_Privacy_Employee Relations and_Legal_Implications_of_Monitoring_Employee_E-mail_Use

The Hamburg Commissioner for Data Protection and Freedom of Information, $1^{\text {st }}$ October 2020, https://datenschutz-hamburg.de/assets/pdf/2020-10-01-press-release-h+mfine.pdf

Treaty on Functioning of the European Union https://eur-lex.europa.eu/legalcontent/EN/TXT/?uri=celex\%3A12012E\%2FTXT

Turkish Constitutional Court, Application No: 2016/13010, 17 September 2020, https://kararlarbilgibankasi.anayasa.gov.tr/BB/2016/13010?BasvuruNoYil=2016\&Bas vuruNoSayi $=13010$

Turkish Constitutional Court, Application No: 2018/31036, 12 January 2021, https://kararlarbilgibankasi.anayasa.gov.tr/BB/2018/31036

https://www.datatilsynet.no/regelverk-og-verktoy/lover-og-regler/avgjorelser-fradatatilsynet/2021/far-gebyr-for-videresending-av-e-post/

\footnotetext{
${ }^{13}$ Barry A. Friedman / Lisa J. Reed, Workplace Privacy: Legal and Employee Relations Implications of Monitoring Employee E-Mail Use, Proceedings of the $13^{\text {th }}$ Annual International Conference 2005, Association on Employment Practices and Principles, September 2005,

https://www.researchgate.net/publication/225577056_Workplace_Privacy_Employee_Relations_and_Legal_Im plications_of_Monitoring_Employee_E-mail_Use p. 34
} 


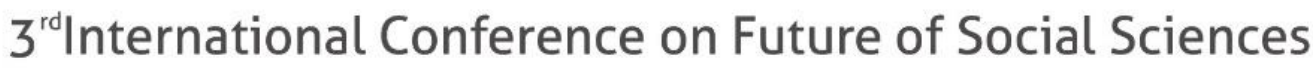

5 - 7 March 2021

BERLIN, GERMANY

https://www.datatilsynet.no/aktuelt/aktuelle-nyheter-2021/far-gebyr-for-ulovligvideresending-av-e-post/

https://www.datatilsynet.no/regelverk-og-verktoy/lover-og-regler/avgjorelser-fradatatilsynet/2021/cyberbook-as-far-gebyr/

https://lfd.niedersachsen.de/startseite/infothek/presseinformationen/lfd-niedersachsenverhangt-bussgeld-uber-10-4-millionen-euro-gegen-notebooksbilliger-de-196019.html https://www.poderjudicial.es/cgpj/es/Poder-Judicial/Noticias-Judiciales/El-TribunalSupremo-confirma-la-nulidad-del-proyecto-de-Telepizza-que-obliga-a-losrepartidores-a-aportar-su-movil-personal-para-su-geolocalizacion 